\title{
Antitumor necrosis factor- $\alpha$ antibodies as a novel therapy for hepatocellular carcinoma
}

\author{
WEI LI ${ }^{1}$ and YONG-BIN JIAN ${ }^{2}$ \\ ${ }^{1}$ Interventional Medical Center, Affiliated Hospital of Qingdao University, Qingdao, Shandong 266555; \\ ${ }^{2}$ Department of Interventional Radiology, Weifang People's Hospital, Weifang, Shandong 261041, P.R. China
}

Received February 27, 2016; Accepted February 14, 2017

DOI: 10.3892/etm.2018.6235

\begin{abstract}
Hepatocellular carcinoma (HCC) accounts for many cases of cancer-associated mortality. Tumor necrosis factor (TNF)- $\alpha$ is a key mediator of tumor-promoting inflammation. It has been demonstrated that anti-TNF- $\alpha$ treatments have preclinical benefits for multiple types of cancer, however their potential for treating HCC remains unclear. Through fluorescence-activated cell sorter analysis and enzyme-linked immunosorbent assay, the results of the current study indicated that TNF- $\alpha$ was strongly expressed in HCC tissues and the HCC cell lines HepG2 and Hep3B. In vitro, anti-TNF- $\alpha$ antibodies (infliximab and etanercept) decreased HCC cell viability via antibody-dependent cell-mediated cytotoxicity and complement-dependent cytotoxicity effects. Infliximab treatment also significantly increased apoptosis in HepG2 and Hep3B cells compared with controls $(\mathrm{P}<0.001$ and $\mathrm{P}<0.05$, respectively). In vivo, anti-TNF- $\alpha$ treatment delayed HCC progression as indicated by the significantly prolonged survival time in an HCC xenograft mouse model $(\mathrm{P}=0.0009)$. Further analyses revealed that anti-TNF- $\alpha$ treatment significantly decreased the expression of pro-inflammatory cytokines, including TNF- $\alpha(\mathrm{P}<0.01)$, interleukin (IL)-1 $\beta(\mathrm{P}<0.05)$, IL-6 $(\mathrm{P}<0.05)$ and IL-17 $(\mathrm{P}<0.05)$ and induced apoptosis in HCC tumors. The results of the current study suggest that TNF- $\alpha$ is a potential target for novel therapeutic strategies to treat HCC. Anti-TNF- $\alpha$ treatments compromised HCC tumor progression by inducing cell death and decreasing levels of pro-inflammatory cytokines.
\end{abstract}

\section{Introduction}

Liver cancer is the sixth most common type of cancer worldwide and was the second most common cause of cancer-associated

Correspondence to: Dr Yong-Bin Jian, Department of Interventional Radiology, Weifang People's Hospital, 5 Guangwen Street, Weifang, Shandong 261041, P.R. China

E-mail: jianyongbin01@126.com

Key words: tumor necrosis factor, hepatocellular carcinoma, inflammation, target therapy mortality in 2015 (1). Hepatocytes are the principal cellular components of the liver, followed by other cells such as endothelial cells and bile duct cells. Hepatocellular carcinoma (HCC), which originates in the hepatocytes, is the most common pathological type of liver cancer, accounting for $\sim 80 \%$ of all liver cancer cases in adults (2). Comprehensive therapeutic strategies have been developed, including surgical resection, radiofrequency ablation, chemotherapy and orthotopic liver transplantation; however, metastasis and recurrence remain major obstacles to HCC treatment. The estimated overall five-year survival rate of patients with liver or intrahepatic bile duct cancer is $18 \%$ (3).

Previous studies have indicated that inflammation is closely associated with HCC development. Persistent infection with either hepatitis $\mathrm{B}$ or hepatitis $\mathrm{C}$ virus, one of the major risk factors of $\mathrm{HCC}$, induces chronic inflammation and subsequent cirrhosis, thus promoting HCC initiation and progression $(4,5)$. HCC patients with high levels of inflammation, marked by increased levels of inflammatory cytokines and cells, tend to have a poor prognosis $(6,7)$. Pro-inflammatory cytokines, including TNF- $\alpha$, interleukin (IL)- $1 \beta$ and IL- 6 , are the principal mediators of tumor-accelerating inflammation (8-10). Therefore, targeting tumor-accelerating pro-inflammatory cytokines may result in HCC tumor regression.

TNF- $\alpha$ was initially identified by its ability to induce lysis in tumor cells (11). TNF- $\alpha$ has two forms: A cell membrane-bound form and a soluble form. Two types of TNF- $\alpha$ receptors, TNF- $\alpha$ receptors 1 and 2 , which are either cell membrane-bound or soluble, have been classified so far $(11,12)$. Although TNF- $\alpha$ was initially identified as a tumor-killing cytokine, further studies have determined that it serves a more complex role in cancer development (13). Furthermore, TNF- $\alpha$ is a key mediator of the cancer-associated inflammatory networks that have strong tumor-promoting properties $(14,15)$. Preclinical studies in various types of cancer, including breast, pancreatic and blood cancer, have suggested that TNF- $\alpha$ stimulates tumor growth in vivo and that anti-TNF- $\alpha$ treatments may suppress tumor progression (16-18). Previous studies have demonstrated that the level of serum TNF- $\alpha$ and a number of other pro-inflammatory cytokines, were significantly higher in patients with HCC compared with healthy individuals, thus increased TNF- $\alpha$ was associated with the occurrence of HCC $(19,20)$. High levels of TNF- $\alpha$ were also associated with increased inflammation in patients with chronic viral 
hepatitis $\mathrm{C}$ (21). These results suggest that TNF- $\alpha$ serves an important role in regulating inflammation in HCC. However, the effects of anti-TNF- $\alpha$ treatments in HCC have not yet been elucidated. The aim of the current study was to investigate the effects of anti-TNF- $\alpha$ treatments on $\mathrm{HCC}$, in vitro and in vivo.

\section{Materials and methods}

Cell line culture. The human HCC cell lines HepG2 and Hep3B were obtained from the Chinese Academy of Sciences Cell Bank (Beijing, China) and Sigma-Aldrich (Merck KGaA, Darmstadt, Germany), respectively. Cells were cultured in high-glucose Dulbecco's modified Eagle's medium (DMEM) supplemented with $100 \mathrm{U} / \mathrm{ml}$ penicillin (both from Thermo Fisher Scientific, Inc., Waltham, MA, USA), $100 \mu \mathrm{g} / \mathrm{ml}$ streptomycin (Sigma-Aldrich; Merck KGaA), 2 mM L-glutamine and $10 \%$ fetal bovine serum (both Thermo Fisher Scientific, Inc.) in a humidified $5 \% \mathrm{CO}_{2}$ incubator at $37^{\circ} \mathrm{C}$. The cells were sub-cultured when they reached $80 \%$ confluence.

Cell viability assay. Cell viability was evaluated using a Cell Counting Kit-8 (CCK-8; Dojindo Molecular Technologies, Inc., Kumamoto, Japan). Cells were seeded in 96-well plates and treated with infliximab (Janssen Pharmaceuticals, Inc., Horsham, PA, USA) and etanercept (Enbrel ${ }^{\circledR}$; Wyeth Pharmaceuticals; Pfizer, Inc., New York, NY, USA) in gradient concentrations $(2,4,8,16$ or $32 \mu \mathrm{g} / \mathrm{ml})$ for $48 \mathrm{~h}$. Cells were incubated with CCK-8 solution for $1 \mathrm{~h}$ at $37^{\circ} \mathrm{C}$, then absorbance at $450 \mathrm{~nm}$ was measured using an MRX II microplate reader (Dynex Technologies, Inc., Chantilly, VA, USA). Relative cell viability was calculated as a proportion of isotype controls according to the following formula: (Treatment - blank)/(control - blank) (22).

Fluorescence-activated cell sorting (FACS) analysis. Cells were harvested from fresh cell culture, dissociated into single cells by trypsinization (Sigma-Aldrich; Merck KGaA). Cell fixation and permeabilization were performed using a commercial FIX \& PERM ${ }^{\circledR}$ Cell Fixation and Permeabilization kit (Thermo Fisher Scientific, Inc.) according to the manufacturer's instructions. The cells were subsequently incubated with primary antibodies directed against TNF- $\alpha$ (dilution 1:200, cat. no. ab6671; Abcam, Cambridge, MA, USA) on ice for $1 \mathrm{~h}$, followed by washing with PBS once. Apoptosis was detected using an anti-cleaved caspase-3 antibody (dilution 1:200; cat. no. ab13847; Abcam). Incubation with primary antibodies was performed on ice for $1 \mathrm{~h}$. Fluorescence-labeled secondary antibodies (dilution 1:1,000, cat. no. A-11034; Thermo Fisher Scientific, Inc.) were subsequently added and incubated for $15 \mathrm{~min}$ at room temperature. Stained cells were washed with PBS three times prior to being analyzed with a FACSCanto II flow cytometer (BD Biosciences, Franklin Lakes, NJ, USA). Data were visualized using Flowing 2.0 software (Turku Center for Biotechnology, Turku, Finland).

Patient samples. Tumor and tumor-adjacent tissues were collected from 5 patients who were diagnosed with HCC at Weifang People's Hospital (Weifang, China) between August and December 2014. A total of 2 of the patients were female and 3 were male. The average age of the female patients was
58.0 (55-61 years) and the average age of the male patients was 52.0 (48-55 years). Fresh tissue samples were collected immediately following tumor resection. They were broken down into smaller pieces and dissociated into a single cell suspension by incubation with collagenase type $\mathrm{I}$ at $37^{\circ} \mathrm{C}$ for $1 \mathrm{~h}$. The single cells were then immediately used for FACS analysis. Prior to ELISA the cell suspensions were centrifuged at $1,000 \mathrm{x}$ g for $5 \mathrm{~min}$ at $4^{\circ} \mathrm{C}$. The cell pellets were subsequently lysed by a radioimmunoprecipitation (RIPA) buffer with a protease inhibitor (Thermo Fisher Scientific, Inc.). No patients enrolled in this study received pre-operative chemotherapy or radiotherapy. Informed consent was obtained from all patients and the protocol was approved by the Local Ethics Committee of Weifang People's Hospital (Weifang, China).

Xenograft mouse model. A subcutaneous HCC model was established using 40, 5-week-old female BALB/c nude mice (weight, 18-20 g) purchased from the Shanghai SLAC Laboratory Animal Co., Ltd. (Shanghai, China), in order to analyze the in vivo activity of TNF- $\alpha$ and infliximab. All mice were kept in a specific pathogen-free environment with $45 \%$ humidity under a $12 \mathrm{~h}$ light/dark cycle at room temperature. The mice had free access to standard food and sterilized water. A total of $5 \times 10^{6} \mathrm{HepG} 2$ cells were injected subcutaneously in the flanks of the mice. One week following inoculation, all mice were randomized into 4 groups ( $n=10$ in each group) each receiving different treatments: i) $10 \mathrm{mg} / \mathrm{kg} /$ week isotype immunoglobulin G (IgG) (control; Thermo Fisher Scientific, Inc.); ii) $10 \mu \mathrm{g} / \mathrm{mouse} /$ week, TNF- $\alpha$ recombinant human protein (Thermo Fisher Scientific, Inc.); iii) infliximab, $10 \mathrm{mg} / \mathrm{kg} /$ week; and iv) $10 \mu \mathrm{g} / \mathrm{mouse} /$ week TNF- $\alpha$ recombinant human protein $+10 \mathrm{mg} / \mathrm{kg} /$ week infliximab. Tumor size and body weight were measured every 5 days. Tumor volume was calculated according to the following formula: Tumor volume $=$ length $\mathrm{x}$ width ${ }^{2} \mathrm{x} \rho / 6$. The survival of all mice was documented. Excessive weight loss $(>20 \%)$, ulceration or any other symptoms of distress were considered as the endpoint of survival analysis and observation. Once any of these symptoms were observed the mouse was sacrificed by cervical dislocation. As the study was performing survival analysis, all mice were ultimately sacrificed by this method.

Antibody-dependent cell-mediated cytotoxicity (ADCC) and complement-dependent cytotoxicity $(C D C)$ assays. For the ADCC assay, human HCC tumor cell lines HepG2 and Hep3B were used as target cells and peritoneal macrophages from $\mathrm{BALB} / \mathrm{c}$ mice were used as effector cells. Target cells were seeded in a 96-well plate (2,000 cells/well) and pre-incubated with infliximab or etanercept $(2,4,8,16$, or $32 \mu \mathrm{g} / \mathrm{ml})$ for $1 \mathrm{~h}$ at $37^{\circ} \mathrm{C}$. In the control group, infliximab or etanercept was replaced with $\operatorname{IgG}$. Subsequently, the target and effector cells were mixed to a ratio of $1: 15$ and incubated for $48 \mathrm{~h}$ at $37^{\circ} \mathrm{C}$. For the CDC assay, target cells were plated in a 96-well plate at a density of 5,000 cells/well. Target cells were then incubated with 5\% fresh guinea pig serum (Sigma-Aldrich; Merck KGaA) with active complements and infliximab or etanercept for $6 \mathrm{~h}$ at $37^{\circ} \mathrm{C}$. Cell viability was determined using the aforementioned CCK- 8 assay according to the manufacturer's instructions. Cytotoxicity in each test was calculated as 
previously described (22). Briefly, the survival rate of the two treatment groups was calculated use the formula: $100 \mathrm{x}$ (cell concentration of treatment group/cell concentration of the control group). The survival rate of control group was defined as $100 \%$ and its inhibition rate was defined as $0 \%$. The curves of the control groups were not illustrated in the figures. The difference in cytotoxicity between infliximab and etanercept treated groups was analyzed by a paired t-test.

Quantification of TNF- $\alpha, I L-1 \beta, I L-6$ and $I L-17$ in HCC xenograft tumor tissues as measured by ELISA. Tumor tissues were dissociated into single cell suspension and cell pellets as described above. They were lysed with a RIPA buffer with protease inhibitor. ELISA was performed for TNF- $\alpha$, IL-1 $\beta$, IL-6 and IL-17 according to the manufacturer's instructions (cat. nos. KRC3011, EM2IL1B, EM2IL6, and 88-7371-22, respectively) (all from Thermo Fisher Scientific, Inc.).

Immunofluorescence. The tumor tissues were collected by resection from the HepG2 xenograft mouse model following sacrifice. The tissues were fixed with $10 \%$ neutral-buffered formalin followed by $70 \%$ ethanol (each for $24 \mathrm{~h}$ at room temperature). The tissues were subsequently embedded in paraffin and cut into $4-\mu \mathrm{m}$-thick sections. The slides were deparaffinized with xylene and rehydrated with gradient ethanol. Antigen retrieval was performed by steaming with Reveal Decloaker (Biocare Medical, Concord, CA, USA) for $40 \mathrm{~min}$. Subsequently, 5\% bovine serum albumin (Thermo Fisher Scientific, Inc.) was added and incubated for $15 \mathrm{~min}$ at room temperature and slides were then incubated with primary antibodies against cleaved-caspase-3 (dilution 1:200) overnight at $4^{\circ} \mathrm{C}$. Alexa Fluor ${ }^{\circledR}$-conjugated secondary antibodies (dilution 1:1,000, cat. no. A-11034; Thermo Fisher Scientific, Inc.) were used to detect the primary antibodies. The slides were incubated with the secondary antibodies for $30 \mathrm{~min}$ at room temperature. Photographs of the slides were captured using an Olympus BX51 fluorescence microscope (Olympus, Tokyo, Japan).

Statistical analysis. All quantification data are expressed as the mean \pm standard error of the mean Differences between individual groups were analyzed by Student's t-test or one-way analysis of variance following Bonferroni's pairwise comparisons. Overall survival was plotted using the Kaplan Meier method and the significance was evaluated by the log-rank test. $\mathrm{P}<0.05$ was considered to indicate a statistically significant difference. All the statistical analyses were performed using GraphPad Prism software, version 6.0 (GraphPad Software, Inc., La Jolla, CA, USA).

\section{Results}

TNF- $\alpha$ is overexpressed in HCC. To understand the role of TNF- $\alpha$ in HCC development, TNF- $\alpha$ expression was evaluated in the human HCC cell lines HepG2 and Hep3B, and tumor and tumor-adjacent healthy tissues from HCC patients. Results from the FACS analysis indicated that TNF- $\alpha$ expression was higher in HepG2 and Hep3B cell lines and tumor tissues compared with control isotype expression (Fig. 1A-C). TNF- $\alpha$ expression was also higher in tumor tissues compared
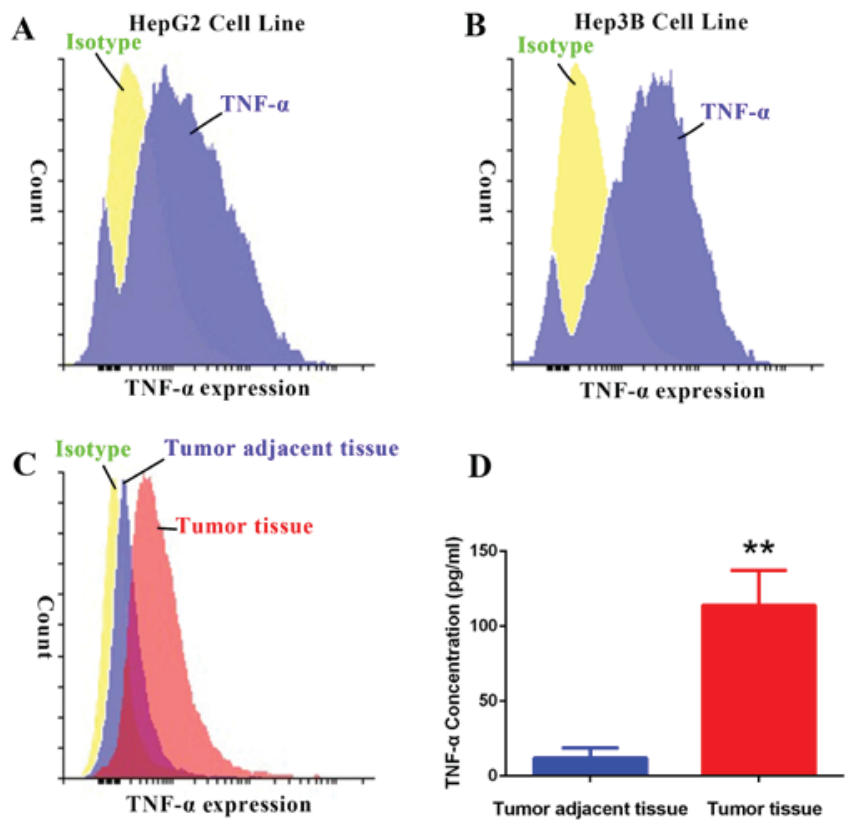

Figure 1. TNF- $\alpha$ expression in HCC cell lines and tissues. TNF- $\alpha$ expression was evaluated in the (A) HepG2 cell line, (B) Hep3B cell line and (C) tumor and tumor-adjacent tissues from HCC patients. (D) Quantification of TNF- $\alpha$ expression in tumor and tumor-adjacent tissues. ${ }^{* *} \mathrm{P}<0.01$ vs. tumor-adjacent tissue. HCC, hepatocellular carcinoma; TNF- $\alpha$, tumor necrosis factor- $\alpha$.

with tumor-adjacent tissues (Fig. 1C). Quantification of TNF- $\alpha$ concentration by ELISA indicated that TNF- $\alpha$ expression was significantly higher in tumor tissues compared with tumor-adjacent tissues $(\mathrm{P}<0.01$; Fig. 1D). These data demonstrate that TNF- $\alpha$ is overexpressed in HCC.

Inhibition of TNF- $\alpha$ reduces viability of HCC cells through $A D C C$ and $C D C$ effects. TNF- $\alpha$ is overexpressed in HCC, therefore the current study investigated whether inhibiting TNF- $\alpha$ expression may be developed as a therapeutic strategy to treat HCC. Infliximab is an anti-TNF- $\alpha$ monoclonal antibody and etanercept is a protein that can bind to the TNF receptor, thus acting as a TNF- $\alpha$ inhibitor. In order to measure the direct cytotoxicity of infliximab and etanercept on HepG2 and Hep3B cells, cells were treated with gradient concentrations of each drug. Following exposure to infliximab and etanercept, the viability of both cell lines was only slightly decreased (Fig. 2A and B), suggesting that inhibition of TNF- $\alpha$ by infliximab and etanercept induces little direct cytotoxicity.

ADCC and CDC assays were conducted to determine the role of anti-TNF- $\alpha$ treatments in HCC cells. In the ADCC assay, it was demonstrated that anti-TNF- $\alpha$ treatment with infliximab or etanercept inhibited HepG2 and HeP3B viability in the presence of macrophages, and this effect was increased as infliximab and etanercept concentrations increased (Fig. 2C and D). Similar effects were observed in the CDC assay (Fig. 2E and F). Exposed to active complements, the infliximab and the etanercept treatments inhibited HepG2 and Hep3B cell viability. However, both cell lines were significantly more sensitive to infliximab treatment compared with etanercept treatment $(\mathrm{P}<0.05)$. These results suggest that anti-TNF- $\alpha$ treatments induced ADCC and CDC effects to inhibit HCC cell viability. 
A

HepG2 cell line
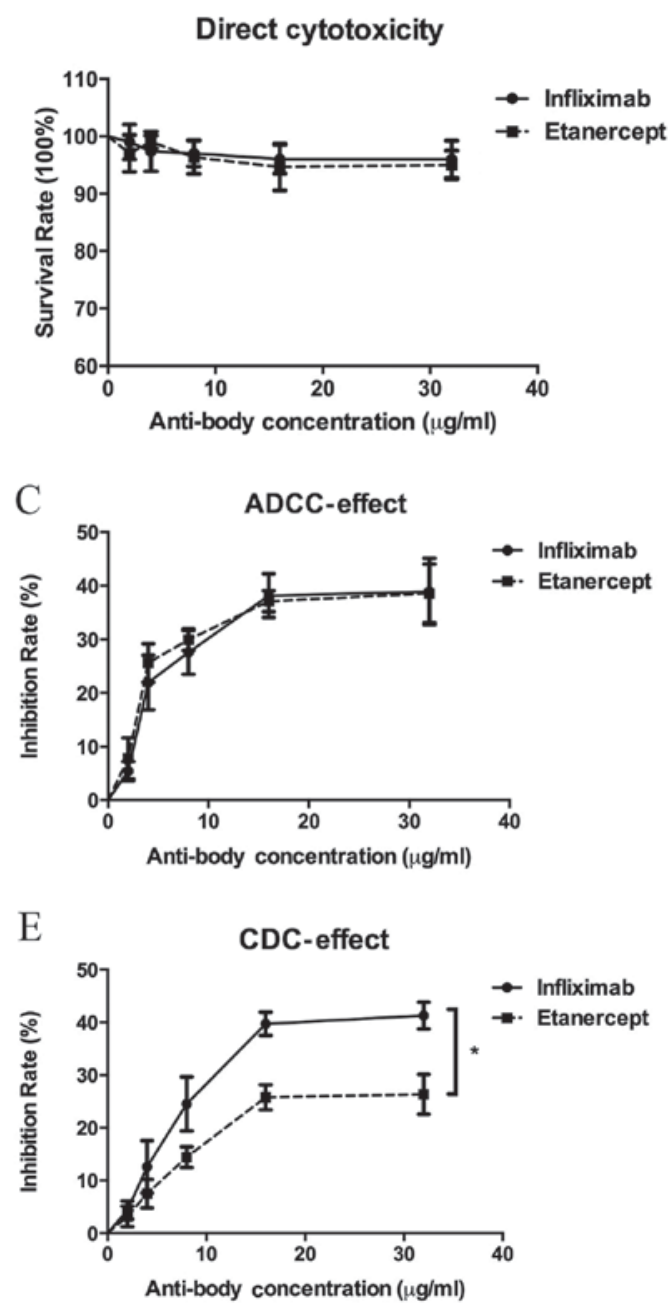

B

\section{Hep3B cell line}
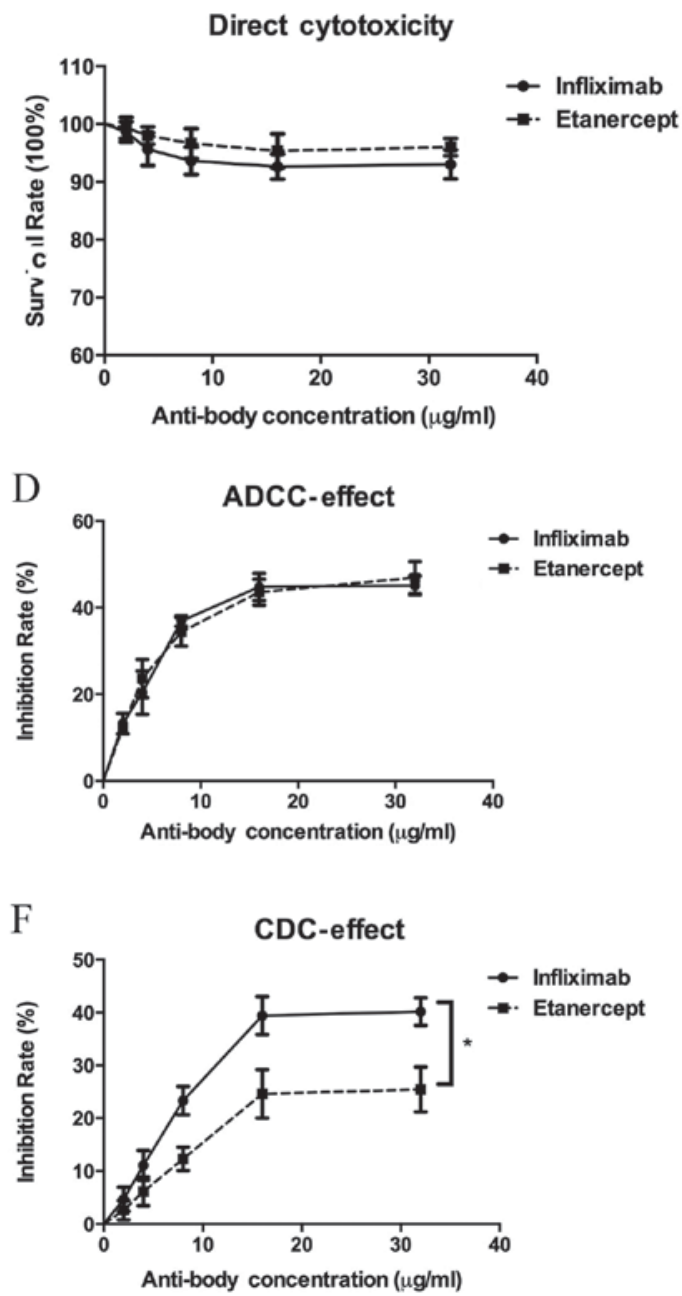

Figure 2. Effect of antitumor necrosis factor- $\alpha$ antibodies on the viability of hepatocellular carcinoma cell lines via ADCC and CDC. No significant differences in the direct cytotoxic effects between infliximab and etanercept were observed on (A) HepG2 and (B) Hep3B cells. No significant difference in the ADCC effects between infliximab and etanercept were observed on (C) HepG2 and (D) Hep3B cells. A significant difference in the CDC effects was observed between infliximab and etanercept on (E) HepG2 and (F) Hep3B cells. * $\mathrm{P}<0.05$. ADCC, antibody-dependent cell-mediated cytotoxicity; CDC, complement-dependent cytotoxicity.

Anti-TNF- $\alpha$ treatment induces tumor regression and prolongs survival in an HCC xenograft mouse model. To evaluate the effects of anti-TNF- $\alpha$ treatment in HCC in vivo, a xenograft mouse model was established by subcutaneously inoculating BALB/c nude mice with HepG2 cells. The mice were then randomized into 4 groups $(\mathrm{n}=10)$ to be treated with isotype $\mathrm{IgG}, \mathrm{TNF}-\alpha$ recombinant protein, infliximab, or TNF- $\alpha$ recombinant protein + infliximab. The tumor growth curve indicated that tumors treated with TNF- $\alpha$ recombinant protein grew faster compared with the mock group (Fig. 3A). The tumors of the group treated with infliximab alone grew more slowly compared with the mock group. Furthermore, treatment with infliximab and TNF- $\alpha$ recombinant protein reduced the rate of tumor growth compared with TNF- $\alpha$ recombinant protein alone.

Consistent with the trends in tumor growth, the survival of infliximab-treated mice was extended compared with the TNF- $\alpha$-treated and control groups (Fig. 3B). In the TNF- $\alpha$-treated and control groups, the estimated median survival of mice was 21 and 24.5 days, respectively. However, in the TNF- $\alpha$ recombinant protein + infliximab-treated and infliximab-treated groups, the estimated median survival times were 30 and 32.5 days, respectively. The log-rank test indicated that the differences among all four groups were statistically significant $(\mathrm{P}=0.0009)$. These data suggested that anti-TNF- $\alpha$ treatment has therapeutic value in $\mathrm{HCC}$ pre-clinical models.

Anti-TNF- $\alpha$ treatment inhibits pro-inflammatory cytokine expression. It has been established that there is an association between inflammation and cancer, including in HCC $(23,24)$. TNF- $\alpha$ is widely accepted as a systemic pro-inflammatory cytokine and a central modulator in inflammatory networks (25). Therefore, the current study investigated the effects of TNF- $\alpha$ recombinant protein and anti-TNF- $\alpha$ treatments on the expression of pro-inflammatory cytokines in the tumor cells of a xenograft mouse model. The cytokines evaluated were IL-1 $\beta$, IL-6, IL-17 
A

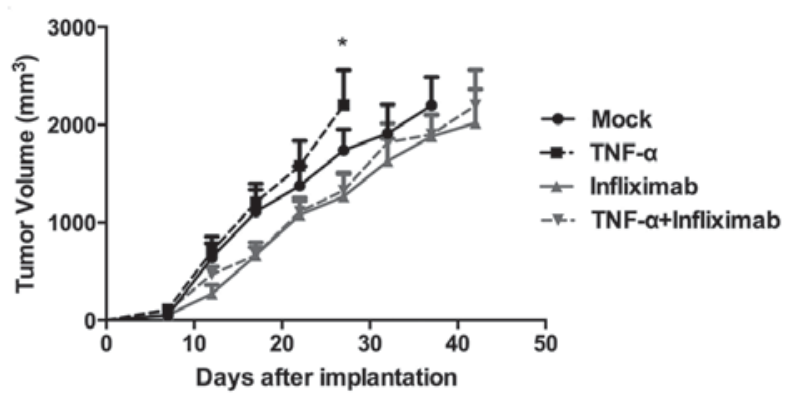

B

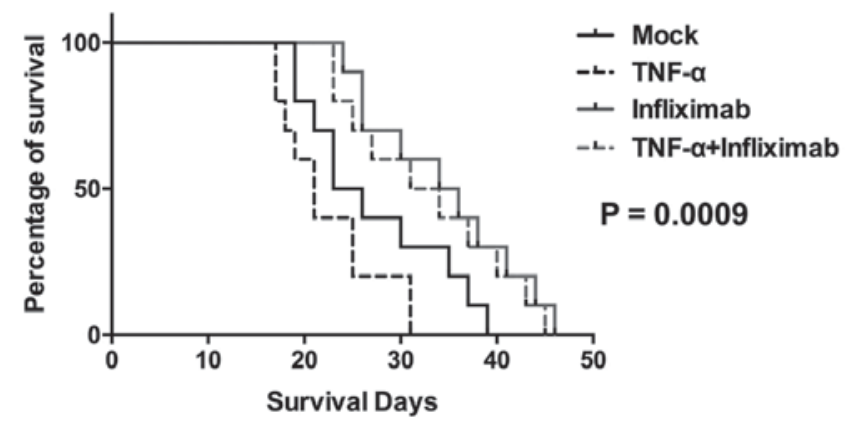

Figure 3. Effect of anti-TNF- $\alpha$ treatment on (A) tumor regression and (B) the duration of survival in a hepatocellular carcinoma xenograft mouse model. The log-rank test $\mathrm{P}$-value of the four groups $=0.0009$. $\mathrm{P}<0.05$. TNF- $\alpha$, tumor necrosis factor- $\alpha$.

A

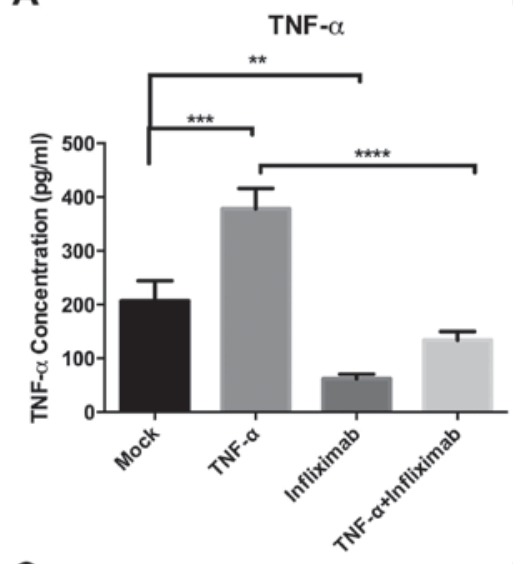

C

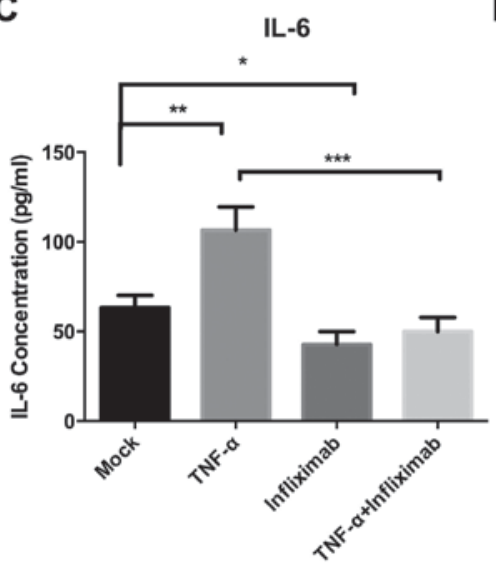

B

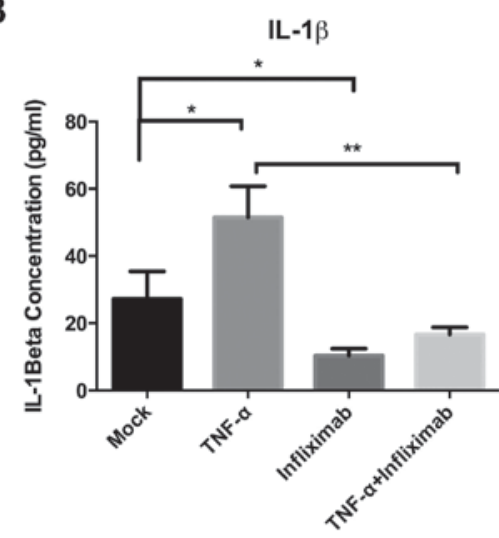

D

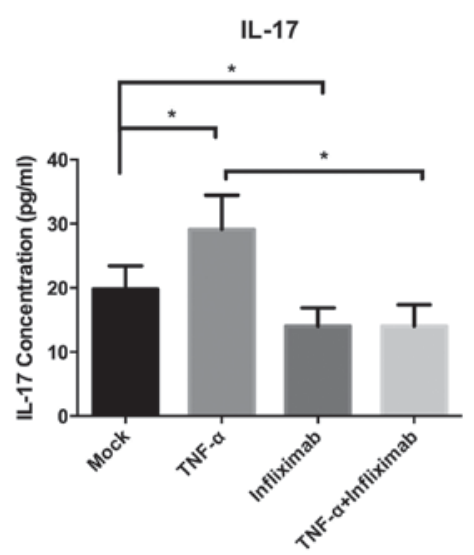

Figure 4. Effect of anti-TNF- $\alpha$ treatment on the expression of the pro-inflammatory cytokines TNF- $\alpha$, IL-1 $\beta$, IL-6 and IL-17 in a hepatocellular carcinoma xenograft mouse model. The levels of (A) TNF- $\alpha$, (B) IL-1 $\beta,(\mathrm{C})$ IL-6 and D (IL-17) were evaluated by ELISA. TNF- $\alpha$ treatment promoted the expression of these cytokines, but infliximab reversed these effects. TNF- $\alpha$, tumor necrosis factor- $\alpha$; IL, interleukin; ${ }^{*} \mathrm{P}<0.05,{ }^{* *} \mathrm{P}<0.01,{ }^{* * * *} \mathrm{P}<0.001,{ }^{* * * *} \mathrm{P}<0.0001$.

and TNF- $\alpha$. It was determined that infliximab significantly decreased the endogenous (infliximab group vs. mock group; $\mathrm{P}<0.01)$ and exogenous (TNF- $\alpha$ group vs. TNF- $\alpha+$ infliximab group; $\mathrm{P}<0.0001$ ) TNF- $\alpha$ in tumor tissues (Fig. 4A). Administration of TNF- $\alpha$ significantly increased the levels of IL-1 $\beta$, IL- 6 and IL-17 in the tumor tissues $(\mathrm{P}<0.05$; Fig. 4B-D). However, expression of these pro-inflammatory cytokines was inhibited by infliximab treatment in the infliximab and TNF- $\alpha+$ infliximab groups (Fig. 4B-D). These data indicated that anti-TNF- $\alpha$ treatment might modulate tumor-promoting inflammation in HCC.
Anti-TNF- $\alpha$ treatment induces apoptosis in vitro and in vivo. To determine whether anti-TNF- $\alpha$ treatment induces apoptosis in HCC, the expression of cleaved caspase-3, which is a common executor in the late apoptosis phase, was measured. In vitro, infliximab-induced ADCC and CDC effects significantly increased apoptosis rates in HepG2 and Hep3B cell lines compared with controls $(\mathrm{P}<0.001$ and $\mathrm{P}<0.05$, respectively; Fig. 5A). Cleaved caspase- 3 was also evaluated by immunofluorescence in HCC tumor tissues from a xenograft mouse model. It was observed that treatment with infliximab markedly increased apoptosis compared with untreated 
A

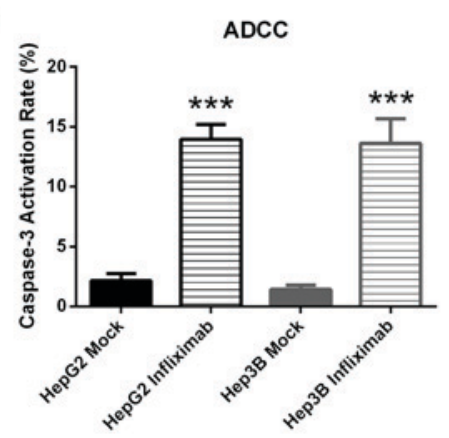

B

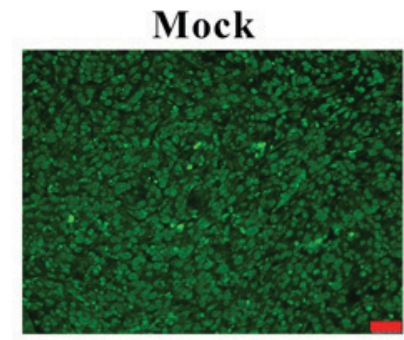

Infliximab

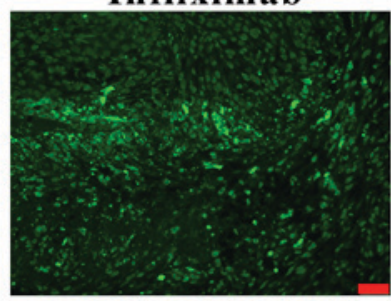

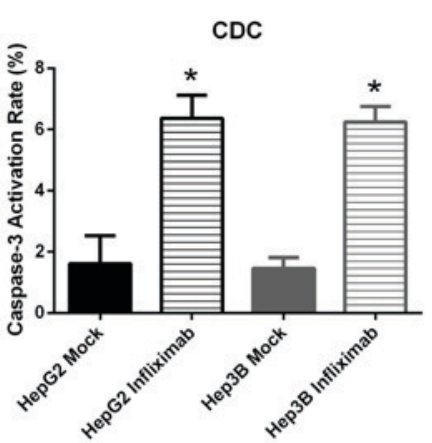

TNF- $\alpha$

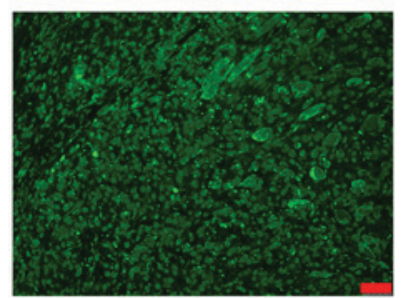

TNF- $\alpha+$ Infliximab

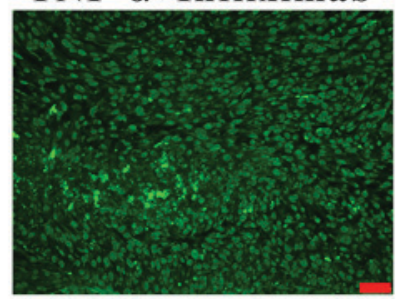

Figure 5. Effect of anti-TNF- $\alpha$ treatment on HCC tumor cell apoptosis in vitro and in vivo. (A) Level of cleaved caspase-3 in HepG2 and Hep3B cells following infliximab treatment in the presence of effector cells or complement. (B) Cleaved caspase-3 expression following infliximab treatment in HCC xenograft mouse model tissues. Magnification, $\mathrm{x} 200$. Scale bar, $50 \mu \mathrm{m}$. ${ }^{*} \mathrm{P}<0.05,{ }^{* * *} \mathrm{P}<0.001$ vs. mock. HCC, hepatocellular carcinoma; TNF- $\alpha$, tumor necrosis factor- $\alpha$.

tissues (Fig. 5B). These results suggested that apoptosis was induced by anti-TNF- $\alpha$ treatment in vitro and in vivo. This is the potential mechanism of $\mathrm{HCC}$ tumor regression by anti-TNF- $\alpha$ treatment.

\section{Discussion}

TNF- $\alpha$ was originally characterized by its tumor cell necrosis effects, however it has also been suggested that TNF- $\alpha$ serves a role in accelerating tumor development $(26,27)$. In cancer, TNF- $\alpha$ is secreted by tumor cells and the surrounding stromal cells, including tumor-associated macrophages and tumor-associated fibroblasts (27). In multiple types of cancer, TNF- $\alpha$ expression is correlated with tumor progression (22). It has previously been reported that $\mathrm{TNF}-\alpha$ is involved with the processes of establishing the pro-inflammatory tumor microenvironment, protecting tumor cells from apoptosis, inducing angiogenesis and enhancing drug resistance (27). In pancreatic and ovarian cancer, it has been demonstrated that TNF- $\alpha$ inhibits cell viability in vitro but accelerates tumor growth in vivo $(17,28)$. Anti-TNF- $\alpha$ treatment with either antibodies or genetic editing has demonstrated therapeutic effects in pre-clinical models, including those for breast cancer, pancreatic cancer and leukemia $(17,22,28,29)$. The treatment of liver cancer remains challenging, as indicated by its low relative 5-year survival rate of $<20 \%$ (3). It has not yet been investigated whether anti-TNF- $\alpha$ treatment has therapeutic value for HCC patients. The results of the current study demonstrated that TNF- $\alpha$ is overexpressed in HCC. Targeting TNF- $\alpha$ with antibodies may have the capacity to induce HCC cell death and compromise the pro-inflammatory tumor microenvironment.

Tumors are made up of tumor cells, surrounding stromal cells, extracellular components and soluble factors including inflammatory cytokines $(30,31)$. Components of the tumor microenvironment are critical in tumor development (32-35). Expression of TNF- $\alpha$ in tumor tissues is elevated during tumor progression and a high level of TNF- $\alpha$ is correlated with poor prognosis in multiple cancer types $(18,27,36,37)$. TNF- $\alpha$ stimulates downstream tumor promoting pathways in cancer cells, which enhance its secretion via a positive feedback loop; this makes it a potential target for antagonists (27). In the current study, high levels of TNF- $\alpha$ were detected in the HCC cell lines HepG2 and Hep3B. FACS and ELISA were used to evaluate TNF- $\alpha$ expression in HCC tumor and tumor-adjacent tissues. A higher level of TNF- $\alpha$ was observed in tumor tissues compared with tumor-adjacent tissues, suggesting that TNF- $\alpha$ is involved in HCC development.

The cytotoxic impact of antibodies on cancer cells may occur via direct cytotoxicity, ADCC or CDC effects (38). It 
was previously reported that anti-TNF- $\alpha$ antibodies had ADCC and CDC effects on cancer cells $(39,40)$. However, in certain types of cancer, infliximab had a higher CDC effect than etanercept (40). In the current study, the results indicated that neither infliximab nor etanercept had direct cell death-inducing functions on HCC cells. However, in the presence of effector cells or complements, infliximab and etanercept inhibited the viability of HCC cells and infliximab had a higher inhibitory rate than etanercept in terms of CDC effect.

The subsequent in vivo investigation supported the findings in vitro. Exogenous TNF- $\alpha$ accelerated tumor growth in the HCC xenograft mouse model, whereas infliximab delayed tumor growth and prolonged survival. Subsequent analyses revealed that anti-TNF- $\alpha$ treatment stimulated apoptosis-mediated cell death both in vitro and in vivo. These data are consistent with previous studies investigating breast cancer and leukemia $(22,29)$.

A large number of inflammatory cells are found in cancer (41). Previous evidence suggests that cancer-related inflammation aids the proliferation of malignant cells, stimulates metastasis and induces immunosuppression (27). When produced by malignant and stromal cells, TNF- $\alpha$ is a major mediator of cancer-related inflammation $(41,42)$. The current data indicated that administration of exogenous TNF- $\alpha$ increased the levels of pro-inflammatory cytokines including TNF- $\alpha$, IL-1 $\beta$, IL- 6 and IL-17 in HCC. Treatment with TNF- $\alpha$ antibody markedly reduced the levels of these pro-inflammatory cytokines, even in the presence of exogenous TNF- $\alpha$. As inflammation is closely associated with HCC, these data implied that anti-TNF- $\alpha$ treatment may have therapeutic value in treating $\mathrm{HCC}$ by helping to neutralize the pro-inflammatory microenvironment.

In conclusion, the current findings indicated that $\mathrm{TNF}-\alpha$ can be inhibited by antagonists in HCC, resulting in tumor regression and improved survival in an HCC mouse model. Further studies investigating the therapeutic value of anti-TNF- $\alpha$ should be conducted in pre-clinical models and subsequent clinical trials.

\section{References}

1. World Health Organization (WHO): Cancer Fact Sheet, 2017.

2. Zhang Y, Ren JS, Shi JF, Li N, Wang YT, Qu C, Zhang Y and Dai M: International trends in primary liver cancer incidence from 1973 to 2007. BMC Cancer 15: 94, 2015.

3. Siegel RL, Miller KD and Jemal A: Cancer statistics, 2016. CA Cancer J Clin 66: 7-30, 2016.

4. Lin MV, King LY and Chung RT: Hepatitis C virus-associated cancer. Annu Rev Pathol 10: 345-370, 2015.

5. Markowitz GJ, Michelotti GA, Diehl AM and Wang XF: Inflammatory models drastically alter tumor growth and the immune microenvironment in hepatocellular carcinoma. Sci Bull (Beijing) 60: 762-772, 2015.

6. Kinoshita A, Onoda H, Imai N, Iwaku A, Oishi M, Fushiya N, Koike K, Nishino H and Tajiri H: Comparison of the prognostic value of inflammation-based prognostic scores in patients with hepatocellular carcinoma. Br J Cancer 107 988-993, 2012.

7. Proctor MJ, Morrison DS, Talwar D, Balmer SM, O'Reilly DS, Foulis AK, Horgan PG and McMillan DC: An inflammation-based prognostic score (mGPS) predicts cancer survival independent of tumour site: A glasgow inflammation outcome study. Br J Cancer 104: 726-734, 2011.

8. Lasry A and Ben-Neriah Y: Senescence-associated inflammatory responses: Aging and cancer perspectives. Trends Immunol 36: $217-228,2015$.
9. Xu J, Yin Z, Cao S, Gao W, Liu L, Yin Y, Liu P and Shu Y: Systematic review and meta-analysis on the association between IL-1B polymorphisms and cancer risk. PLoS One 8: e63654, 2013.

10. Mantovani A, Allavena P, Sica A and Balkwill F: Cancer-related inflammation. Nature 454: 436-444, 2008.

11. Chu WM: Tumor necrosis factor. Cancer Lett 328: 222-225, 2013.

12. Engelmann H, Holtmann H, Brakebusch C, Avni YS, Sarov I, Nophar Y, Hadas E, Leitner O and Wallach D: Antibodies to a soluble form of a tumor necrosis factor (TNF) receptor have TNF-like activity. J Biol Chem 265: 14497-14504, 1990.

13. Chu WM: Tumor necrosis factor. Cancer Lett 328: 222-225, 2013.

14. Mocellin S, Rossi CR, Pilati P and Nitti D: Tumor necrosis factor, cancer and anticancer therapy. Cytokine Growth Factor Rev 16: 35-53, 2005.

15. Zins K, Abraham D, Sioud M and Aharinejad S: Colon cancer cell-derived tumor necrosis factor-alpha mediates the tumor growth-promoting response in macrophages by up-regulating the colony-stimulating factor-1 pathway. Cancer Res 67: 1038-1045, 2007.

16. Hagemann T, Robinson SC, Schulz M, Trümper L, Balkwill FR and Binder C: Enhanced invasiveness of breast cancer cell lines upon co-cultivation with macrophages is due to TNF-alpha dependent up-regulation of matrix metalloproteases. Carcinogenesis 25: 1543-1549, 2004.

17. Egberts JH, Cloosters V, Noack A, Schniewind B, Thon L, Klose S, Kettler B, von Forstner C, Kneitz C, Tepel J, et al: Anti-tumor necrosis factor therapy inhibits pancreatic tumor growth and metastasis. Cancer Res 68: 1443-1450, 2008.

18. Ferrajoli A, Keating MJ, Manshouri T, Giles FJ, Dey A, Estrov Z Koller CA, Kurzrock R, Thomas DA, Faderl S, et al: The clinical significance of tumor necrosis factor-alpha plasma level in patients having chronic lymphocytic leukemia. Blood 100: 1215-1219, 2002 .

19. Aroucha DC, do Carmo RF, Moura P, Silva JL, Vasconcelos LR, Cavalcanti MS, Muniz MT, Aroucha ML, Siqueira ER, Cahú GG, et al: High tumor necrosis factor- $\alpha /$ interleukin-10 ratio is associated with hepatocellular carcinoma in patients with chronic hepatitis C. Cytokine 62: 421-425, 2013.

20. Wang YY, Lo GH, Lai KH, Cheng JS, Lin CK and Hsu PI: Increased serum concentrations of tumor necrosis factor-alpha are associated with disease progression and malnutrition in hepatocellular carcinoma. J Chin Med Assoc 66: 593-598, 2003.

21. Avrămescu CS, Comănescu V, Popescu SN, Turculeanu A, Bălăşoiu M, Popescu CF and Lungulescu M: Correlations among the serum levels of some interleukins and the histopathological aspects in chronic viral hepatitis C. Rom J Morphol Embryol 49: 57-62, 2008.

22. Yu M, Zhou X, Niu L, Lin G, Huang J, Zhou W, Gan H, Wang J, Jiang X, Yin B and Li Z: Targeting transmembrane TNF- $\alpha$ suppresses breast cancer growth. Cancer Res 73: 4061-4074, 2013.

23. Grivennikov SI, Greten FR and Karin M: Immunity, inflammation, and cancer. Cell 140: 883-899, 2010.

24. Castello G, Scala S, Palmieri G, Curley SA and Izzo F: HCV-related hepatocellular carcinoma: From chronic inflammation to cancer. Clin Immunol 134: 237-250, 2010.

25. Bulló M, García-Lorda P, Megias I and Salas-Salvadó J: Systemic inflammation, adipose tissue tumor necrosis factor, and leptin expression. Obes Res 11: 525-531, 2003.

26. Carswell EA, Old LJ, Kassel RL, Green S, Fiore N and Williamson B: An endotoxin-induced serum factor that causes necrosis of tumors. Proc Natl Acad Sci USA 72: 3666-3670, 1975 .

27. Balkwill F: Tumour necrosis factor and cancer. Nat Rev Cancer 9: 361-371, 2009.

28. Kulbe H, Thompson R, Wilson JL, Robinson S, Hagemann T, Fatah R, Gould D, Ayhan A and Balkwill F: The inflammatory cytokine tumor necrosis factor-alpha generates an autocrine tumor-promoting network in epithelial ovarian cancer cells. Cancer Res 67: 585-592, 2007.

29. Zhou X, Zhou S, Li B, Li Q, Gao L, Li D, Gong Q, Zhu L, Wang J, Wang $\mathrm{N}$, et al: Transmembrane TNF- $\alpha$ preferentially expressed by leukemia stem cells and blasts is a potent target for antibody therapy. Blood 126: 1433-1442, 2015.

30. Swartz MA, Iida N, Roberts EW, Sangaletti S, Wong MH, Yull FE, Coussens LM and DeClerck YA: Tumor microenvironment complexity: Emerging roles in cancer therapy. Cancer Res 72: 2473-2480,2012. 
31. Whiteside TL: The tumor microenvironment and its role in promoting tumor growth. Oncogene 27: 5904-5912, 2008.

32. Trédan O, Galmarini CM, Patel K and Tannock IF: Drug resistance and the solid tumor microenvironment. J Natl Cancer Inst 99: 1441-1454, 2007.

33. Ostman A: The tumor microenvironment controls drug sensitivity. Nat Med 18: 1332-1334, 2012.

34. Zhao X, He Y, Gao J, Fan L, Li Z, Yang G and Chen H: Caveolin-1 expression level in cancer associated fibroblasts predicts outcome in gastric cancer. PLoS One 8: e59102, 2013.

35. Zhao X, He $\mathrm{Y}$ and Chen $\mathrm{H}$ : Autophagic tumor stroma: Mechanisms and roles in tumor growth and progression. Int $\mathrm{J}$ Cancer 132: 1-8, 2013.

36. Bozcuk H, Uslu G, Samur M, Yildiz M, Ozben T, Ozdoğan M, Artaç M, Altunbaş H, Akan I and Savaş B: Tumour necrosis factor-alpha, interleukin-6, and fasting serum insulin correlate with clinical outcome in metastatic breast cancer patients treated with chemotherapy. Cytokine 27: 58-65, 2004

37. Karayiannakis AJ, Syrigos KN, Polychronidis A, Pitiakoudis M, Bounovas A and Simopoulos K: Serum levels of tumor necrosis factor-alpha and nutritional status in pancreatic cancer patients. Anticancer Res 21: 1355-1358, 2001.

38. Adams GP and Weiner LM: Monoclonal antibody therapy of cancer. Nat Biotechnol 23: 1147-1157, 2005.
39. Mitoma H, Horiuchi T, Tsukamoto H, Tamimoto Y, Kimoto $Y$, Uchino A, To K, Harashima S, Hatta N and Harada M: Mechanisms for cytotoxic effects of anti-tumor necrosis factor agents on transmembrane tumor necrosis factor alpha-expressing cells: Comparison among infliximab, etanercept, and adalimumab. Arthritis Rheum 58: 1248-1257, 2008.

40. Horiuchi T, Mitoma H, Harashima SI, Tsukamoto $\mathrm{H}$ and Shimoda T: Transmembrane TNF-alpha: Structure, function and interaction with anti-TNF agents. Rheumatology (Oxford) 49: 1215-1228, 2010.

41. Sethi G, Sung B and Aggarwal BB: TNF: A master switch for inflammation to cancer. Front Biosci 13: 5094-5107, 2008.

42. Zhou C, Nitschke AM, Xiong W, Zhang Q, Tang Y, Bloch M, Elliott S, Zhu Y, Bazzone L, Yu D, et al: Proteomic analysis of tumor necrosis factor-alpha resistant human breast cancer cells reveals a MEK5/Erk5-mediated epithelial-mesenchymal transition phenotype. Breast Cancer Res 10: R105, 2008.

(c) (1) $($ This work is licensed under a Creative Commons Attribution-NonCommercial-NoDerivatives 4.0 International (CC BY-NC-ND 4.0) License. 